\title{
検診発見肺癌の特徴と炎の問題点
}

\section{: 兵庫県津名郡に於ける肺癌検診の現状検証を通して}

\author{
Characteristics of Lung Cancer Cases Detected by Mass Survey \\ and Some Problems Involved in Lung Cancer Screening \\ in Tsuna-gun, Hyogo-ken
}

岡田長保・住田良夫・高島康治・田中徳太郎

明石善久 $\cdot$ 大橋高明・伊藤一夫*・絵野幸二**

要旨: 肺癌検診発見肺癌の特徵や検診が内包する問題点を考察するため, 1987 年以降 7 年間に, 兵庫県津名郡に於ける老健法に基づく検診で発見された肺癌23症例(A群)について検証し た。臨床病期は 0，I 期が 13 例 $(56 \%)$ ，根治手術率 48\%，5 年生存率 $48.9 \%, 95$ 年 9 月 現在, 11例が生存中でその内10例までが I 期発見であった. 23例中, 発見前年には受診 歴がない非経年受診群は 12 例, 前年にも受診歴がある経年受診群は 11 例でIIIB期以上の進 行癌は前者に多かった。然し I 期症例の $62 \%$ が前者に属し，その原因は個々の肺癌症例 の肺癌進展速度差にあり, 検診成績を支える予後良好な I 期肺癌の多くは進展速度が緩 やかな症例であった. 又, 検診と同一期間, 同一地域での日常診療発見肺癌 29 症例(B群) との対比でも, length biasを始め種々のbiasが認められ, 進展速度が遅い肺癌はB群よ りもA群に多かった.進展の速い肺癌をできるだけ早期に検診で発見するという困難な課 題が残されている.

〔肺癌 $37(2): 143 \sim 150,1997 〕$

Key words: Characteristics of screen-detected lung cancer,

Problems in lung cancer screening

\section{はじめに}

肺癌検診効果を論議する場合，常に引用され るのが米国におけるMayo Lung Projectの前向 き対照試験による，集検を行っても肺癌の死亡 率は低下しなかったという成績 ${ }^{1)}$ である。一方， 日本では前向き対照試験ではないが, Sobueら厚 生省肺癌検診研究班 (成毛班) の case-control $\mathrm{study}^{2)}$ による, 肺癌検診は肺癌死亡率を $28 \%$ 減

兵庫県津名郡医師会

* 兵庫県総合保健協会

** 兵庫県立淡路病院
少させると推測した報告がある.その後も肯定 的 ${ }^{3)}$ るいは否定的 ${ }^{4}$ 報告がなされている. 著者 らは淡路島に於て, 一郡部の肺癌検診に 9 年間 関与してきたが, 小規模ながら, 検診発見肺癌 症例を検証することにより，検診発見肺癌の特 徵, 検診の現状, 更には現行肺癌検診の内包す る問題点について考察したので報告する.

\section{対象と方法}

兵庫県津名郡 ( 6 町, 人口 64,253 人)では, 1987 年以来, 老人保健法による肺癌検診が実施され, 
Table 1. Eleven surviving cases among 23 lung cancer cases detected by lung cancer screening from 1987 to 1993, as of September 1995.

\begin{tabular}{|c|c|c|c|c|c|c|c|c|}
\hline $\begin{array}{l}\text { Case } \\
\text { No. }\end{array}$ & Sex & $\begin{array}{c}\text { Age } \\
\text { (Years) }\end{array}$ & $\mathrm{BI}$ & Symptom & $\begin{array}{c}\text { Clinical } \\
\text { Stage } \\
\text { T. N. M }\end{array}$ & $\begin{array}{l}\text { Histo- } \\
\text { logic } \\
\text { Type }\end{array}$ & $\begin{array}{l}\text { Treat- } \\
\text { ment }\end{array}$ & $\begin{array}{l}\text { Surviving } \\
\text { time in } \\
\text { months }\end{array}$ \\
\hline 1 . & $\mathrm{F}$ & $\begin{array}{c}63 \\
(1987)\end{array}$ & 0 & None & $\begin{array}{l}\mathrm{I}, \mathrm{p}-\mathrm{T}_{1} \mathrm{~N}_{0} \mathrm{M}_{0} \\
\text { Location : }\end{array}$ & $\underset{\mathrm{r}-\mathrm{S}^{3}}{\mathrm{Ad}}$ & Resected & 96 \\
\hline 2 . & M & $\begin{array}{c}62 \\
(1987)\end{array}$ & $600<$ & None & $\mathrm{I}, \mathrm{p}-\mathrm{T}_{2} \mathrm{~N}_{0} \mathrm{M}_{0}$ & $\underset{\mathrm{r}-\mathrm{S}^{\mathrm{i}}}{\mathrm{Sq}_{\mathrm{i}}}$ & Resected & 93 \\
\hline 3. & $\mathrm{~F}$ & $\begin{array}{c}58 \\
(1988)\end{array}$ & 0 & None & $\mathrm{I}, \mathrm{p}-\mathrm{T}_{1} \mathrm{~N}_{0} \mathrm{M}_{0}$ & $\underset{\mathrm{r}-\mathrm{S}^{3}}{\mathrm{Ad}}$ & Resected & 86 \\
\hline 4. & M & $\begin{array}{c}72 \\
(1988)\end{array}$ & 1800 & None & $\mathrm{I}, \mathrm{p}-\mathrm{T}_{2} \mathrm{~N}_{0} \mathrm{M}_{0}$ & $\underset{1-S^{3}}{\mathrm{Ad}_{2}}$ & Resected & 81 \\
\hline 6. & M & $\begin{array}{c}71 \\
(1989)\end{array}$ & 900 & None & $\mathrm{II}, \mathrm{p}-\mathrm{T}_{1} \mathrm{~N}_{1} \mathrm{M}_{0}$ & $\underset{\mathrm{r}-\mathrm{S}^{3}}{\mathrm{Sq}}$ & Resected & 93 \\
\hline 9 . & M & $\begin{array}{c}73 \\
(1987)\end{array}$ & $600<$ & None & $\mathrm{I}, \mathrm{p}-\mathrm{T}_{1} \mathrm{~N}_{0} \mathrm{M}_{0}$ & $\begin{array}{l}\mathrm{Sg}_{1} \\
1-\mathrm{S}^{6}\end{array}$ & Resected & 93 \\
\hline 15. & M & $\begin{array}{c}59 \\
(1992)\end{array}$ & 0 & None & $\mathrm{I}, \mathrm{p}-\mathrm{T}_{1} \mathrm{~N}_{0} \mathrm{M}_{0}$ & $\underset{\mathrm{r}-\mathrm{S}^{4}}{\mathrm{Ad}_{4}}$ & Resected & 36 \\
\hline 16. & $\mathrm{~F}$ & $\begin{array}{c}65 \\
(1992)\end{array}$ & 0 & None & $\mathrm{I}, \mathrm{p}-\mathrm{T}_{2} \mathrm{~N}_{0} \mathrm{M}_{0}$ & $\underset{1-S^{4}}{\mathrm{Ad}_{4}}$ & Resected & 36 \\
\hline 22. & $\mathrm{~F}$ & $\begin{array}{c}65 \\
(1993)\end{array}$ & 0 & None & $\mathrm{I}, \mathrm{p}-\mathrm{T}_{1} \mathrm{~N}_{0} \mathrm{M}_{0}$ & $\begin{array}{l}\mathrm{Ad} \\
\mathrm{r}-\mathrm{S}^{5}\end{array}$ & Resected & 24 \\
\hline 23. & $\mathrm{~F}$ & $\begin{array}{c}69 \\
(1993)\end{array}$ & 0 & None & $\mathrm{I}, \mathrm{p}-\mathrm{T}_{1} \mathrm{~N}_{0} \mathrm{M}_{0}$ & $\underset{\mathrm{r}-\mathrm{S}^{2}}{\mathrm{Ad}_{2}}$ & Resected & 24 \\
\hline 24. & $\underset{(1993)}{\mathrm{M}}$ & $\begin{array}{c}62 \\
\text { (detected }\end{array}$ & $\begin{array}{c}600< \\
\text { by Spu }\end{array}$ & $\begin{array}{l}\text { None } \\
\text { tum cytology }\end{array}$ & $\begin{array}{l}\text { y) } \\
\text { y) }\end{array}$ & $\underset{\mathrm{r}-\mathrm{S}^{1}}{\mathrm{Sq}}$ & Resected & 24 \\
\hline
\end{tabular}

Age(years) : at the time when lung cancer was detected.

$\mathrm{BI}$ : Brinkman Index Ad. : Adenocarcinoma

Sq. : Squamous cell carcinoma, Sm. : Small cell carcinoma

初期 3 年間の状況については既に報告した5). 1990 年 $(90$ 年と略す)以降は兵庫県総合保健協会のシ ステムが確立され, 津名郡医師会肺癌検診委員 会は津名郡の間接X-P読影を担当し, 医師会員 (参加医療機関数24) は主治医機能を活用して比 較読影などを行い，二次検診に参画した。二次 検診での要精検者は三次専門医療機関に送られ， 確定診断と治療をうけた。87年から93年までの 7 年間に, 主として40才以上の住民, 延べ43,649 人(男: 17,431 , 女: 26,218 , 男女比 $1: 1.5$ )を 検診し, 問診, 間接X-P, 高危険群の喀痰細胞診 により把握された肺癌症例は23例であった。こ の23例 (A群)について検診受診歴, 読影状況, 組 織型, 癌の進展速度差, 自覚症状, 臨床病期, 予後などを検討した. 更に, 検診発見肺癌と日 常診療発見肺癌(非検診) とを比較するため，94 年 9 月, 津名郡内 35 診療所に対するアンケート 調査を行った。その結果, 87 年から 94 年までの 間に集検以外の日常診療で発見された肺癌患者
の内，79才以下で組織型や予後が把握されてい る症例は29例であった。この29例(B群)の受診動 機, 組織型, 臨床病期, 生存率, 死亡率などを 調査した.生存率はKaplan-Meier法により算出 し, 生存症例及び他疾患死の症例は, その時点 での打ち切り症例とした。

\section{結 果}

Table 1, Table 2は87年から93年までの集検 で発見された肺癌症例 $(A$ 群)の概要を, 95年 9 月 時点での生死別に示したものである.症例No. 12 は縦隔腫瘍であったため除外した。年齢, 性, 組織型, 病期別分布はTable 3, 4, 5のA群の欄 に示した，男性では扁平上皮癌が多く，女性は 腺癌のみで, 病期は 0 及び I 期が 13 例 $(56 \%)$ で あった。喀痰細胞診では 3 例(No. 9, 10, 24)が 発見され,いずれも喫煙指数 600 以上の男性で扁 平上皮癌であった。切除率は70\%，絶対的治瘾 切除率 $48 \%, 5$ 年生存率 $48.9 \%$, 生存期間中央 
Table 2. Twelve of the 23 lung cancer cases detected by lung cancer screening from 1987 to 1993 that had died.

\begin{tabular}{|c|c|c|c|c|c|c|c|c|}
\hline $\begin{array}{l}\text { Case } \\
\text { No. }\end{array}$ & Sex & $\begin{array}{c}\text { Age } \\
\text { (Years) }\end{array}$ & $\mathrm{BI}$ & Symptom & $\begin{array}{c}\text { Clinical } \\
\text { Stage } \\
\text { T.N.M } \\
\end{array}$ & $\begin{array}{l}\text { Histo- } \\
\text { logic } \\
\text { Type }\end{array}$ & $\begin{array}{l}\text { Treat- } \\
\text { ment }\end{array}$ & $\begin{array}{l}\text { Survival } \\
\text { time in } \\
\text { months }\end{array}$ \\
\hline 5. & $\mathrm{~F}$ & $\begin{array}{c}68 \\
(1988)\end{array}$ & 0 & None & $\begin{array}{l}\mathrm{I}, \mathrm{p}-\mathrm{T}_{1} \mathrm{~N}_{0} \mathrm{M}_{0} \\
\text { Location : }\end{array}$ & $\begin{array}{l}\mathrm{Ad} \\
\mathrm{r}-\mathrm{S}^{9}\end{array}$ & Resected & 36 \\
\hline 7. & M & $\begin{array}{c}75 \\
(1989)\end{array}$ & 0 & $\begin{array}{l}\text { Bloody } \\
\text { sputa }\end{array}$ & $\mathrm{I}, \mathrm{p}-\mathrm{T}_{2} \mathrm{~N}_{0} \mathrm{M}_{0}$ & $\underset{\mathrm{r}-\mathrm{S}^{2}}{\mathrm{Sq}}$ & Resected & 48 \\
\hline 8. & M & $\begin{array}{c}76 \\
(1989)\end{array}$ & $600<$ & Cough & II, c- $\mathrm{T}_{1} \mathrm{~N}_{1} \mathrm{M}_{0}$ & $\underset{1-\mathrm{S}^{4}}{\mathrm{Ad}}$ & No treatment & 12 \\
\hline 10. & M & $\begin{array}{c}72 \\
(1987)\end{array}$ & $600<$ & Cough & IV, Relapsed & $\begin{array}{l}\text { Sq. } \\
\text { r-Main Br. }\end{array}$ & Radiation & 24 \\
\hline 11. & M & $\begin{array}{c}74 \\
(1990)\end{array}$ & $600>$ & None & $\mathrm{N}, \mathrm{c}-\mathrm{T}_{1} \mathrm{~N}_{2} \mathrm{M}_{1}$ & Sm. & Chemotherapy & 3 \\
\hline 13. & M & $\begin{array}{c}63 \\
(1991)\end{array}$ & $600<$ & None & $\mathrm{II}, \mathrm{p}-\mathrm{T}_{1} \mathrm{~N}_{1} \mathrm{M}_{0}$ & $\underset{1-S^{6}}{\mathrm{Sq}_{4}}$ & Resected & 30 \\
\hline 14. & $\mathrm{M}$ & $\begin{array}{c}69 \\
(1991)\end{array}$ & $600<$ & Cough & IIIB, c- $\mathrm{T}_{4} \mathrm{~N}_{3} \mathrm{M}_{0}$ & $\underset{\mathrm{r}-\mathrm{S}^{6}}{\mathrm{Sq}}$ & Radiation & 24 \\
\hline 17. & M & $\begin{array}{c}63 \\
(1992)\end{array}$ & 0 & None & II, $\mathrm{p}-\mathrm{T}_{1} \mathrm{~N}_{1} \mathrm{M}_{0}$ & $\underset{\mathrm{r}-\mathrm{S}^{3}}{\mathrm{Ad}}$ & Resected & 30 \\
\hline 18. & $\mathrm{~F}$ & $\begin{array}{c}72 \\
(1992)\end{array}$ & 0 & None & $\mathrm{I}, \mathrm{p}-\mathrm{T}_{1} \mathrm{~N}_{0} \mathrm{M}_{0}$ & $\underset{\mathrm{r}-\mathrm{S}^{3}}{\mathrm{Ad}}$ & Resected & 30 \\
\hline 19. & $\mathrm{~F}$ & $\begin{array}{c}43 \\
(1992)\end{array}$ & 0 & None & IIIA, c- $\mathrm{T}_{2} \mathrm{~N}_{2} \mathrm{M}_{0}$ & $\underset{\mathrm{r}-\mathrm{S}^{3}}{\mathrm{Ad}}$ & Radiation & 30 \\
\hline 20. & M & $\begin{array}{c}79 \\
(1993)\end{array}$ & $600<$ & None & $\mathrm{IV}, \mathrm{c}-\mathrm{T}_{1} \mathrm{~N}_{2} \mathrm{M}_{1}$ & $\underset{1-\mathrm{S}^{3,6}}{\mathrm{Sm}}$ & Chemotherapy & 8 \\
\hline 21. & $\mathrm{~F}$ & $\begin{array}{c}71 \\
(1993)\end{array}$ & 0 & None & $\mathrm{IV}, \mathrm{c}-\mathrm{T}_{2} \mathrm{~N}_{1} \mathrm{M}_{1}$ & $\underset{1-S^{10}}{A d}$ & Chemotherapy & 6 \\
\hline
\end{tabular}

BI : Brinkman Index

Table 3. Age and sex distribution in Groups A and $\mathrm{B}^{*}$.

\begin{tabular}{cccccc}
\hline Age & \multicolumn{2}{c}{ Male } & & \multicolumn{2}{c}{ Female } \\
\cline { 2 - 3 } \cline { 5 - 6 } & Group A & Group B & & Group A & Group B \\
\hline $40 \sim 49$ & 0 & 0 & & 1 & 0 \\
$50 \sim 59$ & 1 & 3 & & 1 & 3 \\
$60 \sim 69$ & 5 & 5 & & 5 & 1 \\
$70 \sim 79$ & 8 & 10 & & 7 \\
\hline Total & 14 & 18 & & 9 & 11 \\
\hline
\end{tabular}

* Group A : Cases detected by lung cancer screening

Group B: Cases detected by routine medical consultation

Table 4. Histologic cell type and mortality in Groups A and B.

\begin{tabular}{|c|c|c|c|c|c|c|}
\hline \multirow[b]{2}{*}{ Histologic type } & \multicolumn{2}{|c|}{ Male } & \multicolumn{2}{|c|}{ Female } & \multicolumn{2}{|c|}{ Mortality } \\
\hline & $\begin{array}{c}\text { Group A } \\
\text { cases }\end{array}$ & $\begin{array}{l}\text { Group B } \\
\text { cases }\end{array}$ & $\begin{array}{l}\text { Group A } \\
\text { cases }\end{array}$ & $\begin{array}{l}\text { Group B } \\
\text { cases }\end{array}$ & $\underset{\%}{\text { Group }} \mathrm{A}$ & $\underset{\%}{\text { Group }} \mathrm{B}$ \\
\hline Squamous cell & 8 & 5 & 0 & 0 & 50 & 83 \\
\hline Adenocarcinoma & 4 & 6 & 9 & 7 & 46 & 77 \\
\hline Small cell & 2 & 5 & 0 & 3 & 100 & 71 \\
\hline Large cell & 0 & 2 & 0 & 1 & - & 67 \\
\hline Total & 14 & 18 & 9 & 11 & - & - \\
\hline
\end{tabular}


Table 5. Clinical stages of Group A and Group B lung cancer cases.

\begin{tabular}{cccccc}
\hline \multirow{2}{*}{$\begin{array}{c}\text { Clinical } \\
\text { stage }\end{array}$} & \multicolumn{2}{c}{ Group A } & & \multicolumn{2}{c}{ Group B } \\
\cline { 2 - 3 } \cline { 5 - 6 } & Male & Female & & Male & Female \\
\hline 0 & 1 & 0 & & 0 & 0 \\
I & 5 & 7 & & 5 & 3 \\
II & 4 & 0 & & 4 & 2 \\
III A & 0 & 1 & & 1 & 2 \\
IIIB & 1 & 0 & & 1 & 2 \\
IV & 3 & 1 & & 7 & 2 \\
\hline Total & 14 & 9 & 18 & 11 \\
\hline
\end{tabular}

Fig. 1. Survival curves of Group A and Group B. (Kaplan-Meier method)

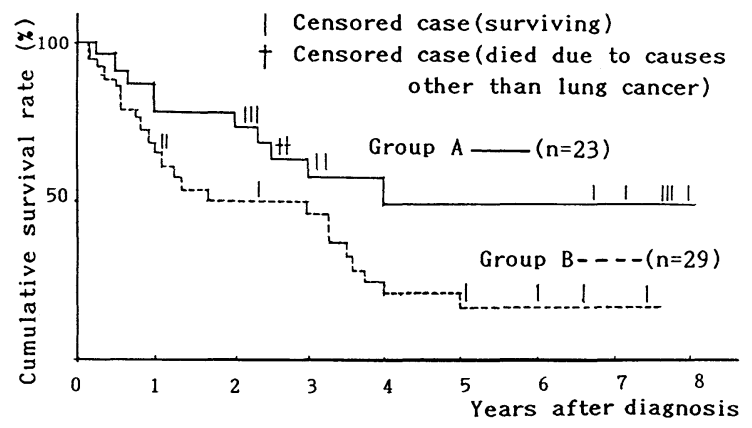

Group A : 23 cases detected by lung cancer screening.

Group B : 29 cases detected by routine medical consultation.
值48月, 11例が生存していた (Fig. 1). 生存症例 群では症例No.6( II 期)以外はいづれも臨床病期 I 期（0 期を含む)で，全例が切除術を受けてい る.死亡症例群では症例No. 5 , No. 7及びNo. 18 (心筋梗塞死)が病期 I 期で, 他 9 例はすべて II IV 期であった。

\section{I．検診受診歴と病期及び予後}

発見前年の受診歴の有無 $($ 経年受診, 非経年受 診)と95年 9 月時点での生死別により各症例を分 類し,Table6に示した。経年受診群は11例 $(48 \%)$ であり，その内 4 例 (No. 8，10，13，19)が肺癌

Fig. 2. Survival curves of 12 deceased cases in Group A and 22 deceased cases in Group B. (Kaplan-Meier method)

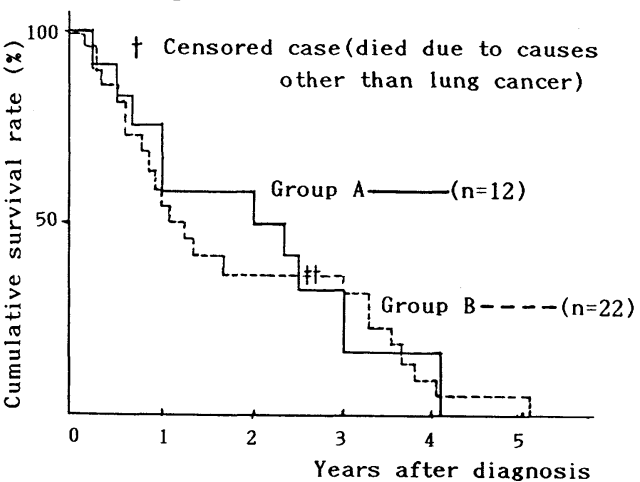

Table 6. Clinical stage and outcome of 23 survey-detected lung cancer cases according to their survey background.

\begin{tabular}{|c|c|c|}
\hline & $\begin{array}{l}\text { Surviving Case No. } \\
\text { (Clinical Stage) }\end{array}$ & $\begin{array}{l}\text { Dead Case No. } \\
\text { (Clinical Stage) }\end{array}$ \\
\hline Screened annually & $\begin{array}{l}\text { No. } 4 \text { ( I ), No. } 6 \text { (II ) } \\
\text { No. } 15 \text { ( I ), No. } 23 \text { ( I ) } \\
\text { ***. } 24 \text { (0) }\end{array}$ & $\begin{array}{r}\text { No. } 8 \text { (II ), No. } 10 \text { ( IV )* } \\
\text { No. } 13 \text { (II), No.19 (IIIA) } \\
\text { ***No. } 17 \text { ( II ), No. } 18 \text { ( I ) }\end{array}$ \\
\hline $\begin{array}{l}\text { Not screened } \\
\text { annually }\end{array}$ & $\begin{array}{l}\text { No. } 1 \text { ( I ), No.2 ( I ) } \\
\text { No. } 3 \text { ( I ), No.9 ( I )** } \\
\text { No. } 16 \text { ( I ), No.22 ( I ) }\end{array}$ & $\begin{array}{l}\text { No. } 5 \text { ( I ), No.7 ( I ) } \\
\text { No. } 11 \text { ( I ), No.14 ( IIIB) } \\
\text { No. } 20 \text { ( IV }), \text { No.21 ( V ) }\end{array}$ \\
\hline
\end{tabular}

* No.10 : Detected by sputum cytology, relapsed in right main bronchus 21 months after previous operation.

** No. 9 , No. 24 : Detected by sputum cytology.

*** No. 17 , No. 18 : Died due to causes other than lung cancer. 
Fig. 3. a) Chest X-ray film of case No. 19 at the time when lung cancer was detected by screening, showing a small shadow in right middle field.

b) Chest X-ray film of case No. 19 taken one year before detection of lung cancer.

c) Chest X-ray film of case No. 19 taken two years before detection of lung cancer.
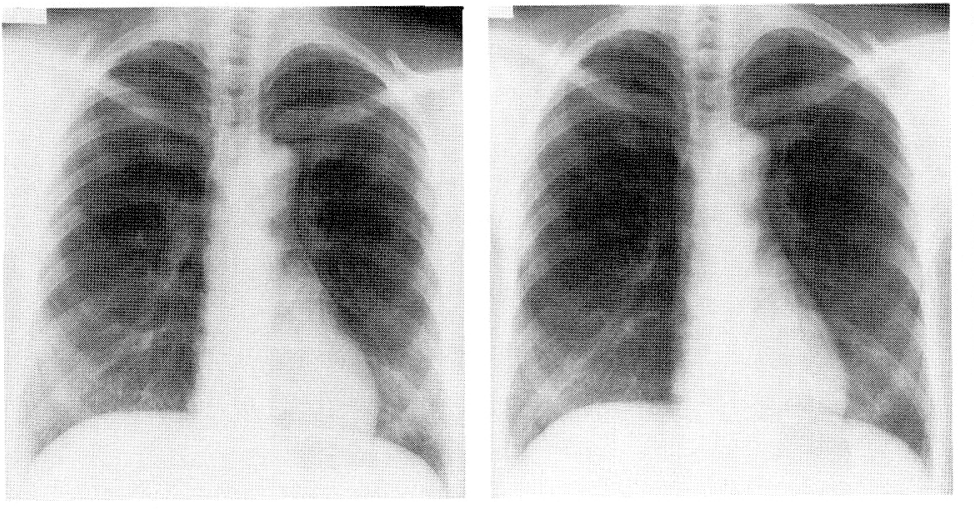

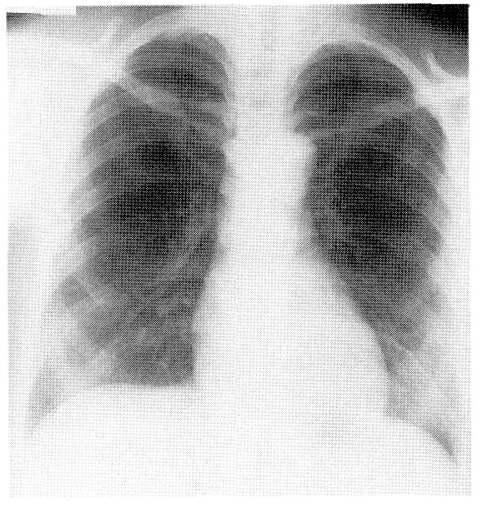

死した $(4 / 11 ， 36 \%)$. 非経年受診群は 12 例，内 8 例が初回検診者であり 6 例が肺癌死した $(6 / 12$, $50 \%)$.この群にはIIIB期以上の進行癌が 4 例あ り, 進展例の比率が高かったが, 反面, 初回検 診で I 期発見, 長期生存中の 4 例 (No. 1，2，3， 9)も存在した。

経年受診にもかかわらず 1 年から 2 年 6 力月 の間に死亡した上述 4 例中, 症例No. 8 は発見前 年及び 2 年前の間接X-Pでの異常影発見は困難で あり, 発見 1 年後に骨転移など極めて速い進展 を示した腺癌であった.症例No.10は喀痰細胞診 による発見で, 1 年 9 力月前の扁平上皮癌切除 後の再発, $\mathrm{I}$ 期の特殊例である.症例No. 13は前 年の間接X-Pで両上肺野の硬化性結核病巣, C判 定, 翌年に左 $\mathrm{B}^{6}$ 入口部狭窄, 未梢部肺炎様院影 により $\mathrm{E}$ 判定, $\mathrm{T}_{1} \mathrm{~N}_{1} \mathrm{M}_{0}$ の扁平上皮癌, 腫瘍径 2.5 $\times 2.5 \mathrm{~cm}$, 術後 30 力月, 右肺転移を伴い死亡した。 症例No. 19は4 4 才女性, 3 年連続受診, 比較読影 による発見時には右中肺野の小不整形影, 肺門 縦隔リンパ節腫大(Fig. 3a, 3b, 3c), 臨床病期 IIIAの腺癌であった. 診断能の限界と肺癌の進展 速度差を示す症例群であった。

\section{2. 組織型と予後}

死亡した 12 症例の中でも, 発見後に極めて速 い経過を示したのが小細胞癌の 2 例 (No. 11, 20) であった.No.11の 2 年前X-Pには異常影が認め られず，発見時にA-P windowの不透明さと縦
隔中央㓌影幅拡大が指摘された。No.20は初回検 診で既に肺内転移があり，IV期であった。徧平 上皮癌と腺癌の予後については症例数が少なく 有意の差は認められなかった(Table 4).

3. 検診受診時の自覚症状の有無と予後

Table 1，2 に示すように, 生存者群には自覚 症状の申告がなく, 死亡者群には 12 例中 4 例の 症状申告が認められた。

\section{4. 間接X-Pのretrospectiveな所見と予後}

経年受診群11例中の死亡 4 例については前述 した。生存中の 5 例, 及び他疾患死の 2 例のう ち, 発見の前年retrospectiveに, 何らかの異常 影が認められたのは 4 例(No. 4, 17, 18, 23)で, 索状影, 胁骨と重なる小斑状影などであった。 生存症例で前年の間接X-Pに異常影が認められな かったのは 3 例(No. 6, 15, 24), 切除腫瘤径は $1 \sim 2 \mathrm{~cm}$, 特に(No. 15, 24) は肺野型早期癌で あった。 retrospectiveに前年の間接X-Pを検討 し，異常影が認められなかった症例は意外に少 ない，前年は受診せず 2 年前に受診していたの は症例No. 11, 14, 16, 22の 4 例で, No. 11は前 述した.No. 14 は 2 年前の異常影指摘は困難であっ たが, 右B ${ }^{6}$ 閉塞の扁平上皮癌( IIIB), 放射線療法 12 力後に死亡した.No. 16,22はいずれもI期 の腺癌で生存中であり, 2 年前X-Pにはそれぞれ 左肺中野の索状影, 右下肺野血管影の収束像が 存在した。このように前年受診, 2 年前受診の 
症例群に共通して認められた事は, 死の転帰を とった症例ではretrospectiveにも異常影を認め にくく(No. 8, 11, 13, 14), 生存症例の過去X-P には 7 例中 4 例に, 何らかの異常影が認められ た(No. 4，16，22，23）という事である. retrospectiveに見直しても異常影が認められないとい うことは, 発癌部位, 或るいは腫瘤径の関係で 現在の方法では早期に発見しにくい症例であっ たか, 又は進展が極めて速い症例であったかの いずれかであろう。逆に, 生存中の予後の良い 肺癌は発見し易い部位に発生したか, 進展速度 が緩やかであったことを推測させるものである。

\section{5 . 日常診療発見肺癌のアンケート調査}

94 年 9 月, 津名郡内の 11 診療所より回答を得 た。最終的には三次専門医療機関で診断治療を 受けた29症例(87〜94年)の概要を, Table 3, 4, 5,7のB群に示した。検診発見群(A群)に比し， 女性の年齢分布は高㱓化し, 組織型では小細胞 癌の比率が増し(A群 : $2 / 23,8.6 \%, \mathrm{~B}$ 群 : $8 /$ $29,27.5 \%)$. 臨床病期は IIIB期以上の進行癌の 比率が高かった(A群： $5 / 23,21.7 \%, \mathrm{~B}$ 群 : $12 / 29,41.3 \%)$. 切除率は $52 \%, 5$ 年生存率は $16.6 \%$, 生存期間中央值は 20 力月であった (Fig. $1)$. 発見時の自覚的有症状率は58.6\%, A群の $17.3 \%$ に比し高率であった。

\section{A，B両群死亡者の生存状況}

Fig. 2に示すように, 早期死亡や後期死亡の状 況は両群間で殆ど変わらず, 予後不良例の背景 因子には両群共通のものがあると思われた。

\section{B 群に属する症例の検診歴}

肺癌診断時から $1 \sim 6$ 年前の検診台帳より検 診歴の有無を調查できた18症例中, 検診歴を認 めた症例は 2 例 (診断の 2 年前, 3 年前 $\mathrm{B}$ 判定), いずれも肺癌発見 (I 期, II 期) は他疾患受診中 であった。

\section{考 察}

兵庫県津名郡は淡路島の北部地域を占め, 人 口移動は少なく，住民の高秢化が急速に進んで いる郡部である (老年人口比率 $21 \sim 25 \%$ )。従っ て高齢者癌の様相を呈する肺癌は確実に増えて いるはずである，津名保健所の死亡統計によれ
Table 7. Symptomatic status of lung cancer cases in Groups A and B at detection.

\begin{tabular}{lcc}
\hline & Group A & Group B \\
\hline Symptoms $(+)^{*}$ & 4 & 17 \\
Symptoms $(-)$ & 19 & 1 \\
Consult due to other diseases & ${ }^{* *}$ & 11 \\
\hline Total & 23 & 29 \\
\hline
\end{tabular}

*Symptoms : Cough, bloody sputum, chest or back pain,etc. ${ }^{* *}$ Other diseases : Diseases other than lung cancer

ば, 呼吸器系悪性新生物の年次別死亡数は89年 29 名 (男 $22, 女 7$ ), 93年38名(男 28, 女10)であっ た. 7 年間年平均 33 名となる. 92 年度の老健法 対象者受診率は $29 \% ， 7$ 年間の肺癌検診発見率

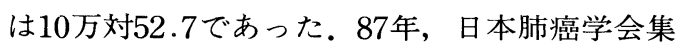
団検診委員会が揭げた当面の目標点 ${ }^{6}$ は，I 期肺 癌の割合を $50 \%$ 以上に，根治手術率を $40 \%$ 以上 にするということであった。津名郡では一応そ れをクリアしたことになる，然し個々の症例を 検討してみると, 検診発見肺癌の特徵や肺癌検 診が内包する問題点が明らかとなった。

I. 検診歴と病期, 予後との関係より

Table 6に示した経年受診群11例と非経年受診 群12例との差は, IIIB期以上の進行癌の存在比 率にあった。問題は I, II, IIIA期についてであ る. 両群の症例数は略同じであるが, I 期症例 の62\%は非経年受診群に属し一見矛盾した結果 となった。問題所在の例証として, 検診初回の 発見で長期生存中の症例No. $2\left(\mathrm{~T}_{2} \mathrm{~N}_{0} \mathrm{M}_{0}\right.$, 径 5 $\mathrm{cm})$ と経年検診予後不良例No. $13\left(\mathrm{~T}_{1} \mathrm{~N}_{1} \mathrm{M}_{0}\right.$, 径 $2.5 \mathrm{~cm})$ とをあげることができる。その他の「初 回検診予後良好例」と「経年受診予後不良例」 も同様である. 又 $「 \mathrm{X}-\mathrm{P} の$ retrospectiveな所見 と予後」で述べたことも肺癌の進展速度差を示 すものであった。肺癌のtumor doubling time は最短30日, 最長1077日との報告があり, 組織 型, 性, 契煙や症状の有無による平均tumor doubling timeの差が認められている7). その長 短症例の存在比率が経年, 非経年受診群の各病 期存在比率に影響し, 特に, I , II 期についての 両群間の差は微妙なものとなり, 死亡率の差も 微妙となる.Table 6で全死因を含めた死亡率で 
は両群は略同率となった。結局, 進展の速い肺 癌は経年検診の早期発見網からも漏れてしまい, 発育進展速度が緩やかな肺癌は非経年検診でも 対応できたことになる，従って，検診成績を支 えるI 期で予後の良い症例の多くは, 発育進展 速度が緩やかな肺癌ということになる。

2.日常診療発見肺癌 (B 群)との対比より

$\mathrm{B}$ 群の症例で発見時から過去 $1 \sim 3$ 年の間に検 診歴が認められた症例の比率は $2 / 18(11 \%)$, 検 診発見肺癌症例(A群)では15/23(65\%)であった。 又, 肺癌発見時に自覚症状を有する症例の比率 は, B群 $58 \%$, A群 $17 \%$ であった。以上の二点か らはB群に受診や診断の遅れが多いことを指摘す ることができる。しかし有症状例の平均tumor doubling timeは無症状例に比し短い ${ }^{7)}$ という報 告があり, 全ての有症状例が受診や診断の遅れ によるとはいえない。とすれば津名郡の検診受 診者群は自覚症状の有無により，一部は既に選 別された集団ということになり，緩やかに進展 する予後の良い肺癌はB群よりもA群により多く 含まれることになる，又，腺癌や扁平上皮癌に 比して予後不良 ${ }^{11}$ の小細胞癌の比率がA群では低 いという事実も認められた。従って両群間には, length bias, lead biasを始胗断治療上, 或る いは個人の意識差など数多くのbiasが存在し, biasを消去せぬ限り， 5 年生存率を始め種々の 指標から検診の有効性を論ずることは出来ない.

\section{3. 検診の精度問題より}

本報告の症例で切除腫瘤径が $1 \mathrm{~cm}$ 大は 3 例(No. $15,23,24)$ に過ぎなかった. 胸部X-Pで写る最
小腫瘍㓌影径は $6 \mathrm{~mm}$ との報告 ${ }^{8)}$ があり, 進展が 速い肺癌のretrospectiveなX-P所見で異常影が 認められなかった症例も, 高速CTの導入により 発見が可能となるかも知れない. しかし，それ が進展の速い肺癌患者の救命につながるか否か は未知数である. 経年検診を生かし, 高速CTの 導入などの検査方法の改善9),10)や, 精検者のきめ 細かい追跡を含めて, どこまで検診診断能力を 向上させることができるかが今後の課題の一つ である。

上記 $1,2,3$ の問題点は, 一地域の肺癌検診 効果が「個々の肺癌患者の肺癌進展速度等の特 性」「地域住民の平素の受診動態」「検診精度」 などの関係から微妙に左右されることを示して いる.

本論文の一部要旨は第64回日本肺癌学会関西支部会(1996 年 7 月 20 日，神戸市)に於て発表した.

本研究を行うにあたり, 肺癌検診全般を推進されまし た兵庫県総合保健協会, 津名郡 6 町の行政当局, 兵庫県 津名保健所, 又, 二次検診にご協力頂きました津名郡医 師会員各位に深謝申し上げます。特に症例を提示頂きま した粟田哲司, 岡本 功, 小山幹人, 西海長平, 曾山信 彦, 津本定也, 柳沢潤子, 諸先生に御礼申し上げます。 併せて兵庫県立淡路病院, 兵庫県立成人病センター, 神 戸大学医学部付属病院, 京都大学胸部疾患研究所, 神戸 市立中央市民病院など, 確定診断治療にご尽力頂きまし た三次病院各位に感謝申し上げます。

\section{文 献}

1) Taylor WF, Fontana RS, Uhlenhopp MA, et al : Some results of screening for early lung cancer. Cancer 47 : 1114-1120, 1981.

2) Sobue T, Suzuki T, Naruke T, et al : A casecontrol study for evaluating lung-cancer screening in Japan. Int J Cancer $50: 230-237$, 1992.

3) 田村哲生, 山下英敏, 筒井大八, 他: 高知県宿 毛市の肺癌検診の有用性の評価 : 検診受診歴を 考虑したlength bias除去の試み。肺癌 35 :735747, 1995.

4) Kubik A, Parkin DM, Khlat M, et al : Lack of benefit from semi-annual screening for cancer of the lung : follow-up report of a randomized controlled trial on a population of high-risk males in Czechoslovakia. Int J Cancer $45: 26-33,1990$.

5) 住田良夫, 清木昌之介, 岡田長保, 他 : 兵庫県 津名郡における肺癌検診について。兵庫県医師 会医学雑誌 $33: 71-76,1991$.

6）日本肺癌学会集団検診委員会：肺癌集団検診の 手びき。肺癌 $27: 225-237,1987$. 
7) 薄田勝男, 斎藤泰紀, 相川広一, 他 : 原発性肺 癌における tumor doubling timeの臨床病理学的 特性. 肺癌 $34: 875-881,1994$.

8) 荒井他嘉司, 塩原順四郎, 塩沢正俊, 他：増大 速度, 発見時の大きさからみた肺野型肺癌の早 期発見に関する問題点. 肺癌 $16: 7-13,1976$.
9）飯沼 武: 肺がん集団検診の費用効果分析一 LSCT検診も含めて。綜合臨牀 $43: 1464-1469$, 1994.

10）本山 新, 河野通雄, 足立秀治, 他 : ヘリカル CTの肺癌 2 次検診への応用 -4 年間の要精検例 の検討. 肺癌 $35: 883-890,1995$.

（原稿受付 1996年 7 月 29日／採択 1997年 1 月10日)

\title{
Characteristics of Lung Cancer Cases Detected by Mass Survey and Some Problems Involved in Lung Cancer Screening in Tsuna-gun, Hyogo-ken
}

\author{
Nagayasu Okada ${ }^{1}$, Yoshio Sumida ${ }^{1}$, Yasuharu Takashima ${ }^{1}$ \\ Tokutaro Tanaka ${ }^{1}$, Yoshihisa Akasi ${ }^{1}$, Takaharu Oohashi ${ }^{1}$ \\ Kazuo Ito ${ }^{2}$ and Kozi Eno ${ }^{3}$
}

1. Tsuna-gun Medical Association, Hyogo

2. General Health Association, Hyogo

3. Hyogo Prefectural Awazi Hospital

In order to determine the characteristics of lung cancer cases detected by lung cancer screening and to clarify some problems involved in screening, a total of 23 cases (Group A) detected by screening conducted under the Health and Medical Services Law for the Aged in Tsuna-gun, Hyogo-ken during the past seven years (1987 1993) were investigated. Of the 23,13 were clinical stage 0 or I $(56 \%)$, the curative resection rate was $48 \%$, the 5 -year survival rate was $48.9 \%$, and 10 of the 11 surviving cases had had clinical stage $\mathrm{I}$. In the 12 cases which had not participated in the survey the year before detection, there were 8 stage I, 1 stage IIIB, and 3 stage $I$. However, in the 11 cases that had participated in the survey in the year preceding detection, there were 1 stage 0,4 stage I , 4 stage II, 1 stage III A, and 1 stage IV case which had relapsed after a previous operation. The above relationship between clinical stage and survey background of each case suggested differences in the growth speed of each lung cancer as well as difficulties in detecting small sized lung cancer. Retrospective surveys of chest roentgenogram in 15 cases and their outcomes also supported the above findings. Most cases with stage I lung cancer showed slow growth. We compared the 23 survey-detected cases (Group A) with 29 lung cancer cases (Group B) detected by routine medical consultation during the same calendar period and in the same areas in which the lung cancer surveys were performed. There was length bias and many other biases between the former and the latter. More cases with slow growth were included in group A than in group B.

The above findings suggest that it is still difficult to detect rapidly growing lung cancers early even by annual lung cancer screening. 